\title{
Development of Learning Models through Relay Games to Improve Fine Motoric Children Aged 5-6 Years
}

\author{
$1^{\text {st }}$ Lidia Vera Bessu \\ Yogyakarta State University \\ Yogyakarta Indonesia \\ Vera06bessu@gmail.com
}

\author{
$2^{\text {nd }}$ Dr. Panggung Sutapa, MS \\ Yogyakarta State University \\ Yogyakarta Indonesia
}

\begin{abstract}
This study aims to determine the effectiveness of learning modelsthrough relay games to improve fine motor skills for children aged 5-6 years. This research and development refers to the Borg \& Gall model. Development design is grouped into 3 steps, namely: (1) preliminary study, (2) development process, and (3) trial and finalization. The subjects of the initial (limited) field trials were 10 children and 1 teacher from the B TK group Sta. Theresia Tunas Harapan. The subject of field trials (broad) was 12 children from one school namely TK Sto. Dominic Weepangali and 15 children from Eben Haezer kindergarten. The operational test subjects were 40 children from Bina Taqwa Islamic Kindergarten. Data collection tools used in this study are interviews and observations. Data analysis techniques using Paired Samples Test with a significance level of 0.05 . The results showed that the model of learning through relay games in terms of material and appearance according to experts was categorized as "very good" and the appearance of the media was categorized as "good". There is a difference in the value of the final learning outcomes between pretest and posttest after using the learning tools resulting from the development of the learning model through relay games with $p<0.05$ which is a significant value of 0,000 . This shows that the learning model through relay games can improve the child's fine motor skills, especially the Islamic Kindergarten Bina Taqwa and Kindergarten St. Dominic.
\end{abstract}

Keywords: motorized smooth relay game learning model

\section{INTRODUCTION}

Children are entrusted or mandated by the Supreme Creator to parents. As a deposit or mandate the child must be properly guarded in accordance with the wishes of the Creator himself (Helma Wati, 2105: 1). This agrees with Suyanto (2005: 1) that children are the next generation of the family and the successor of the nation. How happy parents who see their children succeed, both in education, family, community, and work. Besides being well cared for and cared for from childhood, children must also be educated early on.

Education should know the needs of children to develop their motor skills. Children will be bolder at a young age, so the ability of their small muscles needs to be trained early. Then it takes an appropriate learning model and also the selection of media in accordance with the development aspects to be achieved.

Preschool is a period of play, so a modified game for preschoolers is an alternative to children's skills. The modified game emphasizes the ability of children in groups. Games with a group approach will attract children to participate in the learning process (Lestari \& Ratna, 2016: 217-218). Using the right learning model and the selection of media in accordance with the development aspects that you want to achieve still prioritize the elements of the game. Things that can be said in the game elements are body movements or children's activities.

Learning is needed that can provide effective results and use appropriate media in the development of children's fine motor aspects. Using the learning model through relay games can be fun for children, and the game is interesting and in accordance with the developmental stage of children aged 5-6 years. In connection with the problems described above, the researcher conducted a study entitled "Development of Learning Models of Games Relay to Improve the Development of Fine Motoric Children aged 5-6 Years".

\section{METHODS}

method used in this research is the research and development model Research and Development (R \& D). Research and development are research methods used to produce certain products, and test the effectiveness of these products (Sugiyono, 2010: 333). The steps of the research and development method consisting of 7 steps (potential and problems, data collection, 
product design, design validation, product testing, product revision, final product) can be summarized into 3 stages: Analysis of potential and problems (potential and problems ; data collection), development (product design; design validation), and product trials (product trials; product revisions; final products).

The research design used in the operational test was pre-experimental design in the form of one-group pretest-posttest design. The research design used is as follows:

\section{$\mathrm{O}_{1} \mathrm{X} \mathrm{O}_{2}$}

Figure 1. One Group Pretest Posttest Design

Description:

O1 =Pretest value (before being treated)

$\mathrm{O} 2=$ Posttest value (after being treated)

The stages in this study are

validation, trial, operational testing, data analysis.

\section{RESEARCH SUBJECT}

Subjects The test subjects for the development research that will be conducted include group $\mathrm{B}$ children in St. Dominic Weepangali kindergarten. TK Eben Haezer, and Islamic Bina Taqwa Kindergarten. In the limited trial the test subjects involved 1 class B group child from TK Sta. Theresia Tunas Harapan with 10 research subjects. Whereas in the field trial involving 2 class B groups from Sto. Dominikus Weepangali kindergarten is 13 children and kindergarten Eben Haezer as many as 15 children, so the subjek research is 28 children. Furthermore, to test the effectiveness carried out in group B in the Bina Taqwa Islamic Kindergarten as many as 40 children.

\section{RESEARCH TECHNIQUES INSTRUMENTS}

AND

Techniques used in data collection in this study are interviews and observations. The instrument used is the interview and observation guidelines to determine the child's ability to perform relay games. Assessment is done by checklist on

the observation sheet and analyzed in the form of 15 scoring (Eko P. W, 2009: 238). In the product effectiveness test using normality test with Kolmogorov Smirnov Shapiro-Wilk, homogeneity test using independent sample t-test and to determine the difference between the average pretest and posttest values using the Paired Samples Test.

\section{RESULT}

The product produced in this study is a learning model through relay games to improve children's fine motorbike with the following specifications, this learning model through relay game is packaged in $\mathrm{CD}$ form containing relay game activities carried out by children.

The results of children's observations on the learning model through relay games are described by referring to the score range 1-5. To test for normality and homogeneity. The test results of the relay game pretest and posttest data are as follows.

Table 1. Normality Test Of Pretest and Posttest.

\begin{tabular}{|l|r|r|r|r|r|r|}
\hline & \multicolumn{2}{|c|}{$\begin{array}{c}\text { Kolmogorov- } \\
\text { Smirnov (a) }\end{array}$} & \multicolumn{3}{c|}{ Shapiro-Wilk } \\
\cline { 2 - 7 } & $\begin{array}{c}\text { Statis } \\
\text { tics }\end{array}$ & df & Sig. & $\begin{array}{c}\text { Stat } \\
\text { istic } \\
\text { s }\end{array}$ & df & Sig. \\
\hline $\begin{array}{l}\text { Prete } \\
\text { st }\end{array}$ &, 190 & 40 & 001 & 923 & 40 & 009 \\
$\begin{array}{l}\text { Postt } \\
\text { est }\end{array}$ &, 181 & 40 & 002 & 934 & 40 & 021 \\
\hline
\end{tabular}

Based on the table, significant values are greater than 0.05 for pretest and posttest, so thedata can be concluded that the data is normally distributed.

\section{HOMOGENITY TESTS OF PRETEST VARIATIONS AND POSTTEST}

Table 2. Test results Assuming Homogeneity of Variance pretest

\begin{tabular}{|l|l|l|}
\hline Name of TK & Sig. & Description \\
\hline $\begin{array}{l}\text { Sto.Dominicus } \\
\text { and Eben }\end{array}$ & 0,25 & Homogeneo \\
Haezer & 6 & us \\
\hline
\end{tabular}

Table 3. Results of Homogeneity Variance Posttest

\begin{tabular}{|l|l|l|}
\hline Name of TK & Sig. & $\begin{array}{l}\text { Descriptio } \\
\mathrm{n}\end{array}$ \\
\hline $\begin{array}{l}\text { Sto.Dominikus } \\
\text { and Eben Haezer }\end{array}$ & 0.336 & $\begin{array}{l}\text { Homogene } \\
\text { ous }\end{array}$ \\
\hline
\end{tabular}

Based on the above results obtained sig. to test the pretest homogeneity with sig values. Amounting to 0.256 . While the homogeneity test for posttest with sig value. Amounting to 0.336. Because the value obtained is greater than 0.05 
(p> 0.05). Then it can be concluded that the homogeneity test is fulfilled.

\section{AVERAGE OF PRETEST AND POSTTEST VALUES}

Table 4. Average pretest and posttest values of experimental class

\begin{tabular}{|ll|r|c|r|c|}
\hline & & & & $\begin{array}{c}\text { Std. } \\
\text { Deviati } \\
\text { on }\end{array}$ & $\begin{array}{c}\text { Std. } \\
\text { Error } \\
\text { Mean }\end{array}$ \\
\hline Pair & Pret & 16,95 & 40 & 1,2999 &, 20553 \\
1 & est & 00 & & 0 & \\
& Post \\
& test & $\begin{array}{r}22,90 \\
00\end{array}$ & 40 & $\begin{array}{r}1,2770 \\
2\end{array}$ &, 20191 \\
\hline
\end{tabular}

The average value of pretest in the respondent group of the experimental class was 16.95, while for the average posttest of the experimental class was 22.90. It is absolutely clear that the average experimental class differs between pretest and posttest.

\section{PRETEST AND POSTTEST DIFFERENCES TEST}

Table 5. Test results Differences in the results of the pretest and posttest

\begin{tabular}{|l|l|ll|}
\hline Statistical Test & $\begin{array}{l}\text { Sig. (2- } \\
\text { tailed) }\end{array}$ & Description & \\
\hline $\begin{array}{l}\text { Paired Sample t- } \\
\text { test }\end{array}$ & 0,000 & $\begin{array}{l}\text { There is a } \\
\text { difference. }\end{array}$ \\
\hline
\end{tabular}

On the output of the Paired Samples Test, it can be seen that the sig (2-tailed) value is lessthan 0.05 . That is 0,000 . So it can be concluded that Ho is rejected and $\mathrm{Ha}$ is accepted or the results posttest are betterthan the results of the pretest at the significance level $<0.05$.There is a differencesignificant between the results pretest and posttest.

\section{DISCUSSION}

Fine motor is a movement that involves only certain parts of the body and is carried out by small muscles. Dewi (2005: 2) argues that fine motor is a skill that uses fingers, hands and wrist movements appropriately. This opinion is in accordance with that expressed by Sumantri (2005: 143) that fine motor is the use of a group of small muscles such as fingers and hands which often requires careful eye coordination and hand coordination.

Sujiono (2009: 1.14) also argues, fine motor is a movement that only involves certain body parts and is carried out by small muscles, such as the skill of using fingers and proper wrist movements.
So that this movement does not require energy but requires careful eye and hand coordination and in performing fine motor movements, the child also needs the support of other physical skills and mental maturity.

Yudha and Rudyanto (2005: 118), stated that fine motor is the ability of children to move by using smooth (small) muscles such as writing, squeezing, drawing, arranging blocks and inserting marbles. Similarly, according to Bambang Sujiono (2008: 12.5) states that fine motor is a movement that only involves certain parts of the body and is carried out by small muscle muscles, such as the skill of using fingers and moving the right wrist.

Research conducted by Rosyida Labonati (2012/2013) that through assignment methods can improve children's fine motor skills in group B TK Al-Khairaat Lolu. These conclusions are proven by the increase in fine motor skills of children in the first cycle for the ability to compose beams into a building to be $50 \%$ very good and good, the ability to tie shoelaces increased to $45 \%$ very good and good categories, and the last observed ability is children's fine motor skills in installing shirt shirt buttons are $50 \%$ with good and good categories, these results are obtained from the sum of the two categories that are owned, which are very good and good.

\section{CONCLUSION}

The learning model through relay games is developed in accordance with early childhood development. Activities in relay games are packed in a fun and young form followed, so that children are easy to do and can improve children's fine motor skills.

The development of the learning model through relay produces products that are packaged in the form of learning video CDs equipped with a guide to the implementation of learning.

It can be seen that the sig value. (2-tailed) of $0.000<0.05$ means that it is different and significant so it can be concluded that there is a significant difference in fine motor skills between the initial ability of the child with the final ability after being treated. So it can be concluded that this model is effective in improving fine motor.

\section{References}

Bambang Sujiono. (2008). Physical Development Method. Jakarta: Open University.

Dewi, R. (2005). Various Kindergarten Children Problems. Jakarta: Depdiknas Director General of Higher Education.

Eko Putro Widoyoko. (2009). Evaluation of Learning Programs Practical Guidance for Educators and Prospective Educators. Yogyakarta: Learning Library. 
Helmawati. 2015. Know and Understand PAUD. Bandung: PT Remaja Rosdakarya.

Lestari, Indah \& Ratnaningsih. (2016). The Effects of Modified Games on the Development of Gross Motor Skill in Preschoolers. International Journal of Evaluation and Research in Education (IJERE). Vol. 5. No. 3, pp. 216-220.

Sugiyono. (2010). Admisintration Research Methods. Bandung: Alfabeta.

Sumantri. (2005). Skills Development Model Early Childhood Motorics.
Sugiyono. 2010. Educational ResearchMethods Quantitative, qualitative and $\mathrm{R} \& \mathrm{D}$ approaches. Bandung: Alfabeta.

Suyanto, 2005. Basic Concepts of Early Childhood: Jakarta: Ministry of National Education.

Sujiono, Yuliani Nurani. 2009. Basic Concept of Early Childhood Education. Jakarta: PT Index. 